\title{
How Airships are Likely to Affect War
}

\section{Major B. Baden-Powell Late Scots Guards}

To cite this article: Major B. Baden-Powell Late Scots Guards (1910) How Airships are Likely to Affect War, Royal United Services Institution. Journal, 54:387, 555-581, DOI: $\underline{10.1080 / 03071841009431943}$

To link to this article: http://dx.doi.org/10.1080/03071841009431943

曲 Published online: 11 Sep 2009.

Submit your article to this journal

Џ Article views: 22

Q View related articles $\sqsubset$ 


\title{
HOW AIRSHIPS ARE LIKELY TO AFFECT WAR.
}

By Major B. BADEN-POWELL, late Scots Guards.

\author{
On Wednesday, 8th December, 1909. \\ Field-Marshal Rt. Hon. Earl Roberts, V.C., K.G., K.P., etc., \\ in the Chair.
}

The Crmarman : $-\Lambda$, to my very great regret, I am unable to stay here for. the discussion, I will, with jour permission, say a few words on the subject on which Major Baden-Powell is about to lecture. It is, to my mind, a most interesting subject, more interesting than any other subject at the present time except, perhaps, the coming General Election. Of one thing 1 think we may be sure, and that is, that aerial machines have come to stay with us. What kind of machine will crentually prove the most useful and the most practical to us in war, nobody can at present venture to speak with any certainty. 'Some favour aeroplanes, some dirigible balloons; both have made their mark alrcady, although both are still in their infancy. Before any practical decision can be arrived at, I have no doubt that many improvements will be brought about both in acroplanes and in dirigible balloons. Indeid, day by day improvements are being made. We read of the aeroplane getting higher and higher in the heavens and of the dirigible balloon journeying longer and longer distances. It is merely a matter of trial and of improving faults as they come to light. But that something will be evoked out of all these trials, something which will perhaps astonish those who come after us as much as these present aeroplanes and dirigible balkons have astonished 115 , I have no doubt. We have been interested in reading about the efforts of the Wright brothers: what they have done in America to start this movement; and also what Zeppelin's dirigible balloons have done in Germany. I think we were all startled-I am not sure whether $x \cdot e$ in England were not suddenly wakened up-when M. Bleriot unexpectedly arrived at Dover a few months ago, 1 belicve very lew people thought such a feat could be performed. However, it has been done, and he may be perfectly certain that what has been done now will be thought mothing of a few years hence. Some of you may perhaps have been to Darlington. In the Darlington Railway Station there is an old engine-l think the first that was crer built. I was not quite sure whether this was the case, so I referred to the stationmaster, from whom I received a telegram this morning, in which he says: "Engine No. $r$ here first locomotive to run on public railway, Stockton to Darlington, September 27 th, $1825 . "$ That old engine is a curiosity; it is as different from the present locomotive as it is possible to conceive; and there is no reason why some poople seventyfive or eighty ycars hence may not look upon the aenoplanes now in existence equally as curiosities. Perhaps some of them may be stored in our Museum here. At the time I have referred to, viz., 1825; it was evidently never anticipated that railway trains would go at any great speed. This was made clear to me a few years ago, when I had the honour of being presented with an address by the people of Darlington. On the address was a picture of a railwany train-their first railway trainpassing over the high viaduct at Darlington, drawn by the old engine I 
have wold you of, and a few yards in front of the train is depicted a man on a horse with a red flag for the purpose of keeping the road clear. Now, ne know perfcctly well that a man on a horse cannot go very fast on a railway track. We may conclude, therefore, the intention hias that the train woukd not travel more than 10 miles or so an hour. Now we know that instead of going at that skow rate, we can travel sixty or seventy miles an hour. Why, therefore, we should have any doubt as to what aerial machines may do cventually is to me surprising. What we have now to do is to set to uork ourselves in earnest. We have not done much in England in regard to the matter of aerial machines hitherto. We have been rather waiting to bencfit by the experience of other people; but a.e cannot afford to be behind-hand. Aerial machines may be of the grcatest value in the next war. When that war may cone we do not know, but ne certainly cannot afford to keep ourselves in the background any bonger. We must make our own machines, have our own trials, and above all, have a staff of men trained, ready to adapt themselves to aerial machines is they become introduced. I will not take up your time with nore words. What 1 have said is merely to show you how very interested 1 am in the subject myself. I believe that aerial machincs will be a great feature in future wars, and $I$ am anxious that the country should wake up to the necessity for knowing all about them. We are so strangely apathetic. It is rather a consolation to find that other countries can be apathetic also, for although America is a long way ahead of us in acroplanes and dirigible balloons, she is evidently no better prepared for war than we are, if I may judge by a book I have been reading the last two or three daysa book which in many ways is equally applicable to us. It is called: "The Valour of Ignorance." The object of the book is to show how satisfied people are with themselves, how brave and how confident so bong as they are ignorant. It is a book I rccommend everybody to read. My copy was sent to me by the author, and as soon as I received it I went to the pullishers, Messrs. Harper Bros., to try and get some more copies; but the bookseller said they had never thought it would be a book that would be much read in this country, and so they had only had six copies sent over. I took them all at once. I think it is so valuable a book that I suggested they should cable to New York, and other oopics are coming in tomorrou: It fits England exactly. It is the "valour of ignorance" nhich pervades the whole country. Our people are very brave and very confident because they know nothing about what is going on. What we have to do is to try and wake up the country; make them understand what is going on in the world. They would not be quite so valorous if they only realised what other nations are doing and what will assuredly be in store for them unless they wake up. They may perhaps be as valonous, but they will not be so confident of themselves. This meeting has brought to my mind our apathy with regard to balloons and aero planes, and $m y$ conviction is that it is bccausc we do not belicee in anything happening, that we are content to remain in ignorance. This book, "The Valour of Ignorance,". explains our position, as it apparently explains, to the discomfiture of General Homer Lce, the position of America. It is a wonderful book. I will now ask Major Baden-Powell to read his paper.

\section{LECTURE.}

THIS is a most difficult subject to deal with. If we speculate and wander into the realms of romance, it is easy to 
conjure up vast possibilities; but in stern reality we often find such ideas fall short of practicability. Mluch has recently been said about the great importance of aerial machines in war. But a great deal of this has been proclaimed by those who have had no sort of experience in aeronautics, nor have made any study of the science of war. In France and in Germany large airships have been built and tried with some success. Immediately there goes up a cry from the British Public: "Ve must have airships, too!" If, however, we ask anyone "Why must we have airships? What use are we going to make of them?" we seldom get a satisfactory answer. Either it is that he has not thought about it, or he draws imaginary pictures of the state of affairs which may (or may not) come about in the distant future.

So it seems very necessary for us to carefully consider this matter. I am not suggesting that our responsible authorities have not given the matter their very serious attention-but it is desirable, I think, to have an open discussion, to hear the views of all those experts who are kind enough to give them, so as to let the public know something of the real pros and cons regarding the probable potentiality of air craft.

Alarmists have their uses, however. We hear rumours of one European power having secretly under construction 50 airships, and of another having i4 nearly ready. IVe also hear of experiments having been carried out which prove the practicability of discharging bombs from airships capable of creating the most awful havoc, and so on. Though most of these may be set aside as exaggerations, still, ought we not to be prepared in case such stories should prove to be more or less true? It would be better for us to spend a little money in making preparation to ward off a bogie than for us to be caught napping, in the event of any sudden outbreak of war.

The matter must be looked at from two points of view. One is the immediate future-to look at $w$ hat means re (and other nations) actually passess, or are likely to possess, within a lew months, and to consider how these could be used suppose a war to break out immediately. The other is to look further ahead and consider what preparations we ought to be making in view of possibilities that may arise during the next few years.

The subject of aerial navigation has for long been divided under two headings, and whatever the future may bring, this holds good of to-day. These are known as "lighter than air" and "heavier than air," or more correctly as gas-borne vessels and mechanical lifting appliances.

\section{Dirigible Balloons.}

It has been usual of late to classify these ressels into three different types, called respectively " rigid," "semi-rigid," and "non-rigid." Such classification is, however, misleading. All dirigibles are, and must be, rigid. It is merely a detail of construction as to how they are to be kept in shape. What is 
known as the rigid type is that having an internal framework; the semi-rigid has a large. flat frame fixed to the underneath part; while the non-rigid has a long girder slung below it. In the two latter cases the gasbag is blown out tight by means of a "ballonet," or airbag inside connected to a fan blower in the car.

Given a certain shape, the speed and mancuvring power are quite independent : of how that shape is maintained. Various forms of folding framework have been suggested which would enable a "rigid" airship to be deflated and folded up.

The frame vessel must necessarily be comparatively heavy. Therefore, it must have great capacity to lift the weight, and it is impossible to make a small airship on this principle. As the size is increased the cubic contents will increase at a greater rate than the surface area. Hence, when re come to consider very large vessels, this weight of framework becomes of comparatively less importance.

There are certain other points in $u$ hich these various modes of construction affect their military utility. $A$ frameless vessel possesses the advantage of being portable. But this type if struck by even a small projectile will lose gas, and if the pump supplying air to the ballonet is not sufficiently powerful to counteract the loss, the nose of the vessel will be driven in, the spced lessened, and the manceuvring power destroyed.

As regards the actual aerial strength of the various nations at the present moment, the following table ${ }^{1}$ is probably fairly correct. Considerable uncertainty, however, exists as to the exact number of machines under construction.

\section{Capabilities of Airships.}

Whatever improvements may develop in future, we may at present count on vessels capable of performing as follows :

Specd. - The exact speed through the air of any airship is somewhat difficult to reckon, since the slightest puff of wind makes a considerable difference in aiding or thwarting the pro gress, and this must always be a factor of uncertainty. All practical vessels, however, are capable of proceeding at between 25 and 35 miles per hour through the air.

Height.-The altitude to which a dirigible can ascend is of considerable importance in military machines. In March last the Zeppelin was reported to have risen to a height of 5,600 feet, which was accomplished "entirely with the use of the elevators." Other types have seldom exceeded a height of 4,000 feet.

Distance Travelled. - While most of the military dirigibles have made voyages of a couple of hundred miles, the Zeppelin has covered no less than 360 miles in the air.

Difficulties of Dirigibles.

The typical airship is a most difficult appliance to work in practice. It has to be housed when on the ground against 
storms, and this involves the erection of huge sheds. It would however, often be sufficient to get the machine down into a hollow in the ground such as a quarry, and if airships are to be much used it would be desirable to look out for all natural harbours of this kind, and even improve them by digging and by planting trees around their edges.

$A$ large number of men are required to mancuvre the airship on the ground, to get it in and out of its shed, and so on, and these should be specially trained.

One of the greatest dangers arises from the vast store of inflammable gas contained in the balloon. While the extreme flimsiness of the cover, necessarily very light, renders it very liable to damage.

Meteorological conditions have a great effect on gasvessels. Heat causes the gas to expand, while cold contracts it. $\Lambda$ difference of $40^{\circ} \mathrm{F}$., such as sometimes occurs between mid-day and midnight, would make a difference of one-twelfth the capacity or lifting power. Damp renders the balloon very heavy; snow falling on it may weigh it down and entirely prevent its ascent.

\section{Aeroplanes.}

Though at present only a few machines have been experimented with by various Governments, still, it seems highly probable that all nations will soon adopt some form, and the exact type of the immediate future will probably be one very similar to those now so much used for exhibition purposes.' Though these differ a good deal in detail, yet they are all very much the same as regards their potentialitics. The greatest specd may be taken as about 40 or 50 miles an hour; and very probably more in the near future. The height to which an aeroplane can ascend is still a matter of some doubt. Several different kinds have risen to well over $\mathrm{I}, 000$ feet, and one (Paulhan's) has attained nearly 2,000. ${ }^{1}$ It has been argued that the height will be limited owing to the rarity of the air affecting its capability for support. The best argument against this is the fact that condors and other large birds have been observed soaring above the highest mountains-a height far above that ever likely to be attained by dirigible balloons.

As regards the distance which an aeroplane is capable of traversing, the record to date is Farman's flight of 144 miles in 4 hours 17 minutes.

While one man seems quite able to control a machine for several hours on end, some machines have actually carried 3 men.

As compared to a dirigible, the aeroplane, as we know it, is easy enough to manage on the ground. Three or four men can hold it down in any ordinary wind, and a comparatively

1 Since the lccture was delivered, M. Paulhan has ascended to 4.146 feet in an aeroplane. 
very small shed is sufficient to house it. It is not liable to ignition or explosion to any extent, nor is it seriously affected by atmospheric changes.

\section{Difficuities and Orjections to Aeroplanes.}

I have heard objections raised that it would be impossible to make observations from a machine travelling at over 60 miles per hour. This is, of course, absurd. It is entirely a matter of the distance of the object to be observed. If we travel in an express train it may be difficult to see objects on the permanent way beside the train, but we can watch distant views for minutes on end.

It has also been objected that an aeroplane cannot remain stationary over one spot. It is questionable whether therc would be any advantage in doing so, but possibly for dropping explosives or taking a careful photograph it might be desirable. If, now, a strong wind be blowing (and the wind up at a great height generally blows at a far higher rate than that near the surface) it may be possible to travel straight against it, and progress at a rate exactly equal to that of the wind, that is the machine would remain stationary as far as the earth is concerned. This is the method adopted by hawks to hover over their prey, and they, we know, can remain absolutely stationary. Then again, when at a good height the propellers may be stopped and the machine allowed to fall for a certain distance, vertically. Even by travelling around one can remain nearly over one point, sufficient at all events for observation.

\section{Dirigibles and Aeroplanes Compared.}

The advantages of a dirigible as compared to an aeroplane for the purposes of war may be summarised thus:-1. It can, especially if constructed for the purpose, rise to heights far greater than those hitherto attained by aeroplanes. Against this it may be asserted that there is a praclical limit to the height. At 5,000 feet the air is only about five-sixths of the density it is at sea level: so that a balloon which requires 100,000 cubic feet of gas to lift it off the ground would need 120,000 to keep it afloat at 5,000 feet up. This means that the ballonet should be one-sixth of the total capacity of the balloon-and this is probably getting near the limit of practicability. As aeroplanes have actually attained heights of nearly 2,000 feet it seems quite probable that they may soon be able to rise as high as the airship. 2. That they can rise more quickly, by discharging ballast. Though in the emergency of a duel between the two this may give a temporary advantage it would not be of much avail if the aeroplane be able to ultimately attain the same height and progress at a greater speed. 3. As hitherto made, airships can carry a greater weight of passengers or ammunition, etc.; but, considered in the light of expense, half-a-dozen aeroplanes could be made to carry as much, and far larger 
aeroplanes may probably be made. 4 . If the engine stops it is not compulsory to descend. This may sometimes be of advantage, as repairs may be effected in mid-air, and a suitable wind may carry the vessel back to its own country. 5. Can remain in the air for a long time, in calm or in favourable wind, without running the engines. This, however, would very seldom be of importance. 6. Can remain stationary over one spot, for observation or dropping missiles. This could only be in calms and very light winds, as it would be most difficult to remain steady in a puffy wind.

Now as to the advantages possessed by an aeroplane over the balloon :-1. Mluch smaller and easier to manage on the ground. (Usually, however, in war time there is no lack of men to assist). 2. It is far cheaper, more quickly made, and easily repaired in the field. (But cheapness in war material should never be considered; efficiency is the only criterion). 3 . The aeroplane is comparatively invulnerable; its wings may be riddled with bullets and even shells without serious effect. 4. It is not affected, at all events to anything like the same extent, by atmospheric changes. The upper surface of a dirigible extends for something like ten times as much as that of an aeroplane of equal lift. If this be wetted, it may be doubled in weight. 5. It can travel faster, and the speed seems likely to be very greatly. increased in future. 6. Being so much smaller it is not so easily seen, and presents a smaller target.

\section{Difficulties of Afrial Navigation.}

One of the great difficulties in connection with aerial navigation is the danger of losing the way in for or cloud. If a vessel loses sight of the land for any time it is very liable to go astray. If it be quite calm the course may be pursued and an idea of the position obtained by dead reckoning, but there will nearly always be some wind, and considering the great variability both in force and in direction at various heights, it becomes almost impossible to take them into account. It is a frequent experience in ballooning to find, on rising above a cloud bank, that the direction is completely changed. Fog should affect dirigibles more than aeroplanes, since, in practice, the latter are able to skim along within a few feet of the ground, and therefore koep "in touch," while the dirigible, for various reasons, can seldom make any certainty of manceuving at less than 200 or 300 feet up. On the other hand, it would be somewhat dangerous for the aeroplane to be travelling at full speed in a fog so close to the ground, whereas the airship may slow down.

Darkness, too, does not add to the ease of finding one's way, especially in a strange country. The lights of towns are the principal, if not the only, guides, and they may be purposely extinguished in war time. Even if the general locality be ascertainable, accurate and useful information would be difficult to obtain, and attack on any special object would probably be futile. 
One of the great difficulties that a dirigible, and to a less extent an aeroplane, has to deal with, is the velocity of the wind. From statistics.we find that in England the average velocities are about as follows :-

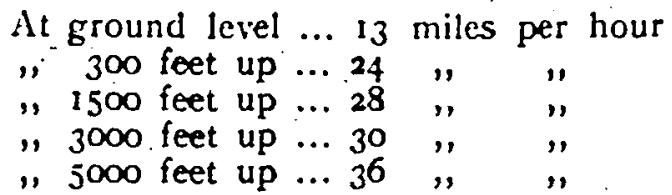

It is thus evident that a dirigible capable of travelling 35 miles an hour through the air-about the best now in existencecould not at 5,000 feet up make any progress against the wind on an average day. This seems very significant, and another interesting point is that in Germany the winds are not so strong, especially at a height; hence, perhaps, the comparative success of the German airships. At Lindenburg the following figures were obtained :-

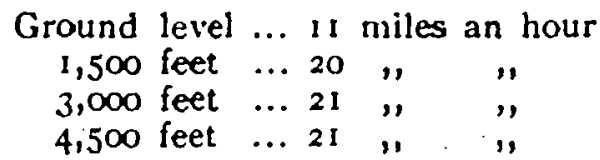

So that here a Zeppelin could, on an average day, travel 14 miles an hour dead against the wind. It is certain that the average wind at sea is greater than on land, but I have not come across any statistics to show whether the same increase with elevation occurs.

There is one point that must be always borne in mind, though an airship may be able to stem a wind, and go one or two miles an hour faster, it is not of much practical use unless it can go say 10 or 15 miles an hour against the wind.

\section{Uses to Which Aerial Machines May be Applied.}

It may be useful to suggest all the possibilities one can think of when these machines might prove of use. Some of them may sound rather visionary at present, but they are, nevertheless, worth bearing in mind, and it would be interesting to hear what others have to suggest on these points.

\section{I.-Reconnaissance.}

Speaking generally, it may be said that the only use of aerial machines that has actually been tested and proved of use (in mancuvres) is for reconnaissance. Whether they may prove useful for other purposes is a matter of conjecture. Yet, after all, this reconnaissance, as soldiers well know, is usually of far greater importance than such a matter as discharging a few explosives. It is more important for a general to receive detailed information about all that is going on in the enemy's lines than for him to be able to destroy a few hundred men or devastate a store. 
When scouting by aerial machine is compared to that system hitherto in vogue-the cavalry scout-it will readily be realised how great is the superiority of the former. To receive reports from all along a line that the scouts have been fired upon gives but little real information. There is the curtain -what is behind it? That curtain can scldom be penetrated. IVith any form of apparatus capable of travelling in the upper regions for even a few miles, complete, reliable and full information is obtainable of the enemy's position, movements, armament and even numbers.

As has been pointed out by Colonel Capper, aerial reconnaissance is of two kinds-tactical and strategical. For the former it would seldom be necessary to travel more than to or 15 miles, but as it would be in the presence of the enemy it might be necessary to keep very high to avoid fire. With the latter, journeys of 40 or 50 miles would be necessary. It might seem, then, as if very large vessels, capable of travelling hundreds of miles, were unnecessary. These, however, may have their special work apart from reconnaissance, and, moreover, they may be able to start from and return to their permanent base, which may be hundreds of miles from the actual field of operations, whereas smaller vessels would have to have a mass of stores carried into the field. But it does not seem necessary, as has been suggested, for a large vessel to go far over the enemy's country for reconnoitring purpases. For instance, if France were at war with Germany, no great benefit would be derived by sending an airship to hover over Berlin.

It is probable that the policy of the French Government has been to provide for tactical reconnaissance by supplying each of its frontier fortresses with an airship capable of mancuvring all about the frontier without necessitating a voyage of more than 20 or 30 miles.

For surveying country a great deal of time and work may be saved by utilising aircraft. A series of photographs taken from above soon provides material for the compilation of an accurate map.

$$
\text { II.-Transport of Troops. }
$$

Though it has been suggested that large bodies of troops could be transported over long distances by dirigible airships, the idea seems hardly feasible. Even if in future much larger vessels are constructed than are dreamt of to-day, it seems unlikely that one would ever carry more than say roo armed men, so that an enormous fleet would be required to take any considerable force, and the matter is altogether beyond the scope of present-day practice.

As regards the aeroplane, it is different. If such machines continue to develop as they have done, it is quite probable that they will soon be used in hundreds, if not thousands. In all probability we shall soon have machines capable of carrying three or four men in addition to the driver. Then the aeroplane 
may be looked upon much in the same light as the motor car; but, going straight across country, independent of roads, regardless of all obstacles, and travelling at a high rate of speed, it would be infinitely more efficient. Such " mounted infantry" would be transported to any tactical position and deposited there within a few minutes, and the machines sent back for reinforcements. Eventually this might even become a means of invading a country.

\section{III.-Discharge of Explosives.}

As regards the damage to be done to troops, stores, buildings, etc., there seems to be a great divergence of opinion. Certain it is that towns can be bombarded with hundreds of large shells without suffering very materially. Explosives are not very harmful unless enclosed in a strong and heavy shell, at least that seems to be the more generally held opinion of experts. Troops are not likely to suffer very greatly unless in compact formations, and they can rapidly be deployed on the appcarance of an airship. It is possible that much might be done by an airship hovering over a fortificd place during bombardment, especially by directing artillery fire. Much harm might be caused by travelling over an enemy's country and dropping bombs or incendiary shells into powder magazines, stores and suchlike, or possibly causing some destruction to bridges and railways. Such trips can only be done with the full risk of losing the airship, so would usually only be carried out for very special objocts.

Though it may not be easy to make accurate shooting by simply dropping a bomb on to a target beneath, yet, doubtless, instruments and appliances will be devised for effecting this.

\section{IV.-Raids.}

Under this heading I include all excursions into an enemy's territory for some special purpose. Numerous instances could be quoted as examples. A railway may be destroyed-not by dropping bombs on to it, which would have a doubtful effectbut by a party being landed near the spot to carry out the demolition. So powder magazines, gun factories, and other places of very great importance in the conduct of war, even though they may be at a great distance from the frontier, may suddenly be attacked, perhaps during the night, by a few men from an airship, and practically destroyed. Even posts on the line of communication, convoys of stores, telegraph offices, and so on, could be raided at any time.

\section{V.-Communications and Dispatch Carrying.}

For communicating with a besicged place any form of airship is, of course, ideal. Though it has been urged that it may not be possible to carry any large amount of provisions or ammunition, yet that is a matter of circumstance. If we 
have a dozen or fifty aerial machines continually going to and fro unmolested, a very considerable amount of such stores could be taken into the place. This work can be carried on during the night, as powerful and unmistakable lights could be displayed in the town or other places to guide the airships.

For communicating with detached posts they would often prove useful. Despatches could be carried more quickly. through the air than by any other means.

\section{VI.-In Savage Warfare}

much could be done. The moral effect on an ignorant enemy would be great, and a few bombs would cause serious panics. In a country where few roads exist, so rapid a means of communication would be most important. With no fear of artillery fire, or of the opposition of similar appliances, an airship would be at its best.

$$
\text { VII.-As Cavalry. }
$$

It may sound curious to speak of an aeroplane being used as a substitute for a cavalry horse, yet it seems possible that a small, compact form (like Santos-Dumont's "Demoisclle") might almost be used in such a capacity. Such a machine could probably be built for $\mathcal{L}_{\mathrm{I}} \mathrm{oo}$, and the manipulation, to a thoroughly trained man, need not occupy much more of his attention than would that of the horse. Able to shim over the country, surmounting hedges and ditches, walls, and even rivers, travelling at an average speed of perhaps 5 or 6 times that of the horse, the advantages for reconnoitring would certainly be very great. The machine would probably be less vulnerable than the horse, and would not offer a very much bigger target. Though the fuel supply might be more difficult than the forage, yet such machines could easily be sent off fifty miles or more to get their supply - and be back and ready for duty within a few hours.

$$
\text { VIII.-As a Look-out. }
$$

As a coign of vantage for the commander-in-chief during an action, a good airship would be unsurpassed. It would be presumed that constant communication could be kept up by wircless telegraphy or otherwise, and it would probably only be used to make short flights from one spot to another, and to take advantage of such a view of the whole battlefield as could not be obtained by any other means. But here again all depends upon the ability of the hostile artillery or air fleet.

$$
\text { IX.-Naial Warfare. }
$$

The advantages of an airship as compared to a marine ship are-(1) Probably greater specd, especially with the wind; (2) enables a wide view to be obtained; (3) ability to rise to a great height to avoid projectiles; (4) ability to get vertically above an 
enemy; (5) enables observer to see to a depth below water. For reconnaissance then, it may prove of great value for the first two reasons. As to an airship actually attacking a battleship, if the latter be provided with a number of special highangle guns it would seem impracticable, seeing that the aerial vessel is not likely to be able to do much harm unless it can get vertically overhead, and in attempting to get there it is very liable to be shot down. Here again, by taking advantage of clouds or in darkness, it may be different, but the accurate discharge of the projectiles would also become much more difficult. Marine vessels unprovided with suitable guns, such as transports, may be more at the mercy of a dirigible.

Reconnoitring at sea is very different to what it is on land. Usually it means merely noting the presence of vessels and their number, etc. Now a flet may be clearly seen at, say 30 miles off, whereas at this distance practically no useful information could be obtained of land forces. Therefore an airship floating high above its fleet would be able to give most timely information about the enemy.

Reference has already been made to the difficulty of navigating an airship in fog. Much the same difficulty holds when over the ocean out of sight of land. It would certainly then be difficult to ascertain one's position; and if the waves gave one some kind of indication of the direction of the wind, it would still be most difficult to calculate one's course, since the direction of the wind on the water level may be different to that higher up.

\section{Fighting in the Air.}

\section{Dirigible v. Dirigible.}

The efficiency of a dirigible for fighting against a similar kind of machine is a móst important consideration. If one nation possessed a type of machine which, in this respect alone, was superior to that of the enemy, it might soon oust the hostile airship and leave that nation supreme in the air-a most enviable position. Such power may be derived from :-

1. Invulncrability, which may be achieved to some extent by division of the balloon into compartments, and possible armour protection to the engine, and perhaps to the crew. Uninflammable gas, such as ammonia or steam, has been suggested, but this would necessitate a balloon of double the size. A frame prevents the bag caving in through loss of gas by a small puncture.

2. Ability to rise high. With machines as now constructed, if one vessel is able to get directly above another it has it at its mercy-a mere lighted match or a burning fuse or grenade dropped upon it would cause its instant destruction. A few holes made by any heavy articles thrown over, or by bullets even revolver bullets, would cripple its action. The upper machine could even descend right on to the lower one and "ram" it. 
It is said that in the latest type of Zeppelin means are provided whereby a man can ascend to the top of the vessel, whence, presumably, he could fire up at an opponent overhead, or could direct the vessel so as to avoid as far as possible being directly underneath the enemy. But even this only mitigates to a very small extent the danger of such a position. A dirigible in the air secing a hostile one on the ground should be able to destroy it.

3. Effeclive Armament. A vessel provided with some form of light gun, or other good means of offence, could soon put out of action one not so provided.

4. Specd may also have something to say, but it would only be desirable in order to run away in safety were the opposing vessel otherwise superior, or to chase a slower going one and destroy it.

Aeroplane v. Dirigible.

Such would seem likely to be a very one-sided sort of fight. It has been compared to that of a hawk and a heron. The advantages to be obtained by the dirigible in being able to rise to a height hitherto not attained by an aeroplane, and being able to ascend more quickly in an energency, have already been discussed. It may carry a better armament; on the other hand it has the great disadvantages of offering a large target, and of being very vulnerable, the skin being so easy to penetrate. The aeroplane with its greater speed, better manceuvring power, and less liability to damage, has an immense advantage. Altogether it seems highly probable that very soon aeroplanes will be constructed which will be able on every point to hold the advantage over the balloon, and being so much less costly and easier to make, can be employed in larger numbers, and so Riould be likely to render the employment of dirigibles quite out of the question.

\section{Aeroplane v. Aeroplane.}

We are now beginning to get into a subject a little beyond our capability of perception. If it be granted that both machines must be travelling at a very rapid pace, and that they are not very vulnerable to bullets, it looks at first as though they were not able to do one another much harm. To collide would probably prove fatal to both. If one got just above the other and could travel at exactly the same rate, some damage could be caused by dropping grenádes, etc., but the damage is not likely to be of such consequence as is the case with a balloon. It is possible that grappling irons suspended below the aeroplane could be used to upset the lower one, or a trailing rope carried to foul its propellers.

Evidently the manceuvring of two aeroplanes fighting in mid-air would form a most interesting spectacle to those below. Ease of mancuvring and speed will evidently be valuable factors, and a machine carrying rwo or more men armed with sifles would soon have the better of a single-man machine.

VOL. LIV. 


\section{Armaments of Airships.}

Seeing that in any kind of aerial craft, lightness and ease of manipulation are bound to be desired, it seems improbable that large guns can be carried, at all events in such vessels as we have to-day. A few rifles, perhaps of large bore, may be sufficient, and some form of rocket would unchoubtedly be most effective against gas-balloons. Eventually it may be possible to use something in the nature of a pom-pom.

As regards explosive bombs, which may possibly be carried, a good deal of diversity of opinion seems to exist. As I have said, it is doubtful if a charge of explosive carried in a light case is likely to do much harm, whereas if enclosed in a strong shell the weight would soon mount up. It is reported that grenades weighing golbs, each have been made for trial by the German Government. Some form of incendiary bomb would be useful for dropping on balloons or for setting on fire stores, magazines, etc.

A missile of the nature of a dart with knife-like barbs could be made very light, and used for dropping on to balloons beneath, to cut holes in the envelope. The application of various chemicals have been suggested which would set light to hydrogen on coming in contact with it.

\section{Land Deyence Against Attack by Airship.}

So long as we have no efficient aerial war machines, it is of the utmost importance for us to make such provision as we can in case war broke out with a power which possessed a number of such ressels.

Guns. First it is evidently necessary to immediately arrange for guns to be made or adapted to fire at a high angle. Every likely point of attack, such as arsenals and stores, even though far inland, should have arrangements for defence. Special guns should be mounted around it, and other appliances such as rockets, kites, etc., kept ready. Our present existing high-angle ro-inch guns can fire at an elevation of $70^{\circ}$, and could hit an airship travelling below 7,000 feet at any range up to 5,000 yards distant, although Colonel Stone, in a recent lecture, considered this no very adequate means of defence.

Several guns have recently been devised for the special purpose of firing at airships. Krupp has made several kinds, Ehrhard has a special gun mounted on a motcr, and VickersMaxim have recently produced a new howitzer. I have not the time now to give further details of these guns.

Aerial Torpedoes on various different principles have lately been invented and tried. Some are of the nature of improved rockets, some are airships controlled by wireless telegraphy. But it is premature to give any opinion upon their efficiency.

It might be possible to form a sort of acrial mine-field similar in principle to a submarine mine-field, around any place 
to be defended. When danger threatened, a number of kites, or, in the absence of wind, small captive balloons could be let up to a great height-say 4,000 or 5,000 feet-with explosive mines and electrical equipment. These should be arranged every few hundred yards apart right round the position. Any hostile aerial vessels trying to pass this cordon kould have to approach within a hundred yards or so of the torpedo.

Mlusketry. Eren rifle bullets can ascend to a good heightthere is a diversity of opinion as to the exact effective rangeand, if not able to nteck a dirigible, may wound aeronauts, damage engines, and so puncture the balloon as to prevent its being able to return to its country.

ciuns on motor-cats are hardly likely to be able to successfully follow an airship, seeing that the latter may be going 30 miles an hour straight across country, while the motor has to go round by road. But they may be useful in rapidly moving to take up positions to protect any special district. If it was desired, for instance, to concentrate some force secretly, and move it to some place unknown to the enemy, balloon-destroying guns should be posted at intervals all around to try and drive off prying airships.

Forlifications may be improved by overhend cover and bombproof shelters. Explosives and ammunition must be stored in wells and underground magazines.

\section{Conclusions.}

To my mind there can be no doubt that the machines which are now actually in existence, both dirigible balloons and aeroplanes, can be made great use of in war; and it seems fairly certain that in another few years time their efficiency will be greatly increased. If properly used, not by ones and twos, but by hundreds, they will without doubt greatly affect our methods of warfare. Reconnaissance will be so much more efficiently carried out that the commiander of a force will not be embarrassed hy that uncertainty and lack of information which so often prevents him from taking the initiative. Operations will be quickened, and wars more rapidly lost or won. Raids into the enemy's country, which it seems impossible to entirely prevent, will, on the other hand, tend to hamper and delay his actions, and spread the zone of operations over the whole country.

Let us not forget that machines are now actually in existence that can come over, without warning, from the Continent, and it is more than possible that they might be the means of causing considerable damage to us, even risking their own loss thereby. Therefore, we must, and at once, make due preparation to defend ourselves against any such aggression.

I can now only hope that these few suggestions will be fully discussed by some of those I see here, who are more competent than myself to judge of the future possibilities of aerial warfare. 


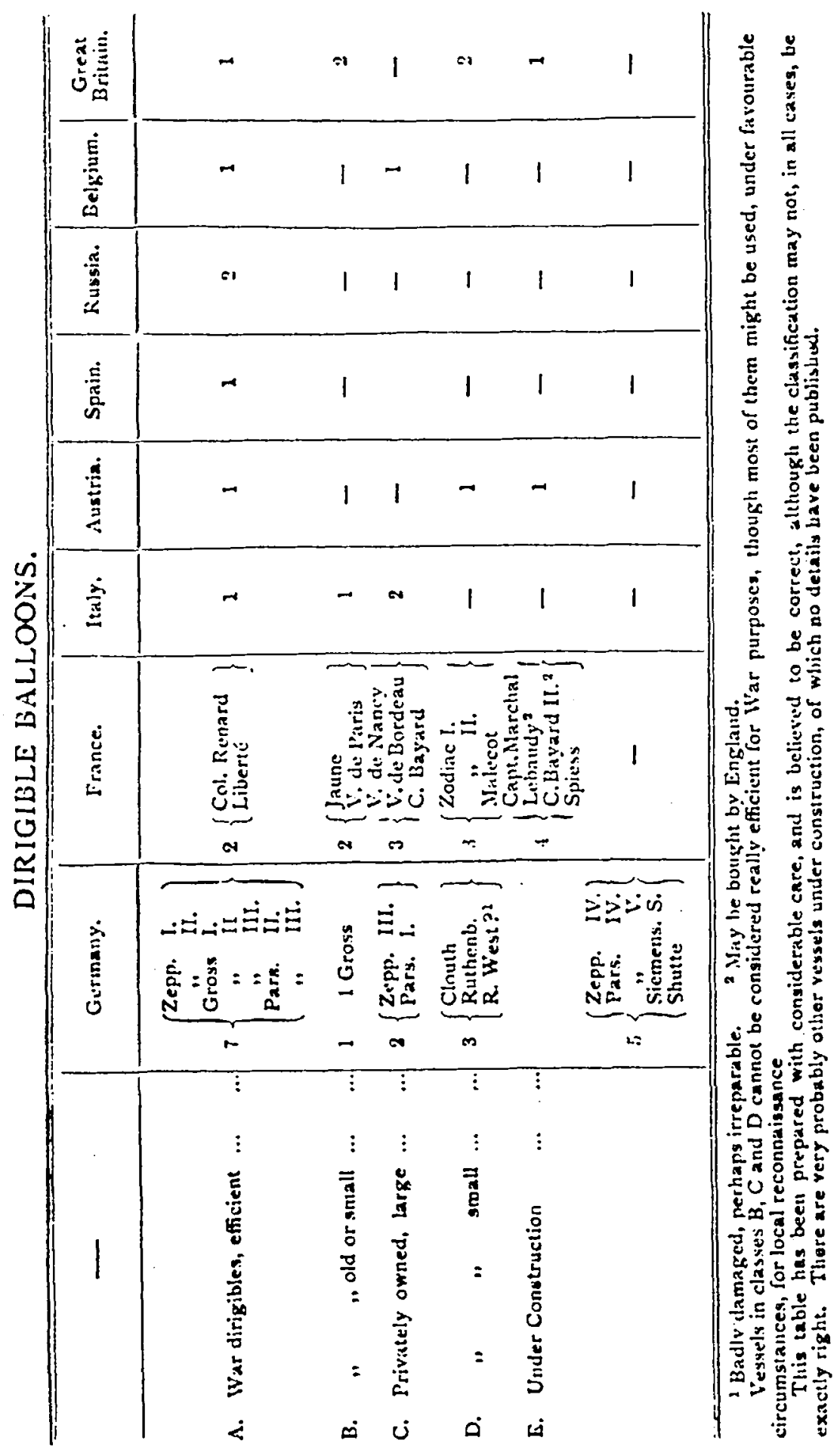


The Cinuruas (Earl Roberts):--May I now ask Adniral of the Fleet Sir Gerard Noel to take ny place.

[Earl koberts here left the meeting, and the Chair was taken for the remainder of the procecdings by Sir Gcrard Noel.]

Coloncl J. G. C.srrek, C.B., K.E. (Commandant of Balloon School) :First of all I think the lecturer is much to be congratulated on tlic lecture he has given 115 , and also he is to be very much congratulated on the audience he hus this afternoon. The size of the audience, I thith, shows how greatly the general interest in this subject has increased within the last year or two. We have had one or two ketures in this Theatre on similar subjects, but none of them have been in any way attended by an audience of this size, and I find that all over the country the perple arc gradually waking up to the importance of this nost iniportant novelty. At the beginning of Major Baden-l'owell's lecture l must say 1 was a little disappointed; I thought that he was merely adrocating expenditure in acrial machines to nard off a bogic, but as he warmed up to his subject, I am glad to say that he appeared to have quite a different vien; and at the end he went to the length of saying practically that he hoped in the next war we should be prepared to use these machines not in tens, but in husdreds. If other nations have these machines to bring against us and we have not, I think it will be very serious for us. If they have not, I do not see that that shoukd be any reason why we should shot do our best to arm vurselves in every possible way for any coming conflict. If they are foolish enough not to have them they are in the position if savages and we are in the position of civilised warfarcrs. At any ratce, ue ought to make the best of any new weapon of warfare that can be evolved. Generally speaking, I heartily agree with the lecturer in what he said, but I should like to offer some suggestions on one or two points that 1 have noted. I think perhaps the lecturer takes a sonew hat exaggrerated vien of the difficulty of aerial navigrition when weather conditions are adverse. Fog is, of coursc, a very great hindrance to any form of transil either by land or by sea. Even railuays, with lines laid don'n for them, are hampered by fogs, and any vehicle that has mo lines laid down for if to keep to must be still more hampered. Airships certainly arc more hampered than ordinary land vehicles; but it must be remembercd that logs are very often local, and that they are often very thin. Whereas you can see for comparatively short distances looking along the ground through the fog, wen you get up into them you can often sec a great deal more than you uould imagine. Another point is, that when you are fairly certain of your direction-although it is quite true, as the lecturer says, that at different elevations the wind changes in direction with surprising suddenness, so that you may actually by rising 1,000 or 2,000 feet change your course by as much as $90^{\circ}$ or more-you have the great advanlage in a dirigible balloon of being able to keep at the same altitude, a thing which is most difficult to do in a free balloon. If you know your course--and the course of a current of wind at the same altitude is very constant, rarely making any sudden changes of direction for considerable lengths of time-you can go on and be fairly certain of the gencral direction in which you are travelling, working on a compass bearing. I do not think there is much difficulty in korking in clonds, becaluse I should not anticipate that one rould stay in the clouds for very long. My oxn experience of clouds is that even in a free balkon it is not often that you stay for a very long time in them without getting some sort of breat: 
through which you can see the ground. In a dirigible balkon, if for the sake of hiding yourself you are keeping in the bottom of a cloud, it is only a matter of a few hundred feet to come out of it, and you only need to stay out for a few minutes to locate yourself from time to time with fair certainty. On clear nights there are so many things, if you have good maps, that will help you, that with practice I do not think we shall have such very great difficulties. Practice at working at night is everything, as soldiers know nowadays. Men who come fresh to the work lose their way very easily at night; but it is extraordinary how in even one season of night manceuvres the men improve in every possible way. It was surprising to me, who had little experience of them, when I went out one night, to sec liow, even on a misty night in a place without any landmarks, officers and men seemed absolutely certain of their position. The author has mentioned some distances which could be covered by tactical or strategical airships; but I think myself he has put much too small a task before them 1 do not anticipate that any airship that can only go to or 15 miles will be of much practical use. Unless it took up a very small proportion of fuel, the engine it could take up would enable it to go but very very sfowly. It must be remembered that the distance travelled is dependent upon the amount of fuel carried. You have to have a big airship in order to get your speed. We cannot at present get a speedy airship without also making it large. The amouint of fuel used is under a pound per horse-power hour, and sufficient to take the balloon 100 or 150 miles is is large proportion of the total weight of the airship and its crew. I do not quite agree with the author as to the strategical reconnaissance. He says that no great benefit in a war between France and Germany would be derived by sending an airship to hover over Berlin. That may be true, but I think great benefit would be received by the French if they knew that large reinforcements were coming by railway from different parts, south or north, or were moving at considerable distances along the frontier in-certain directions. All large concentration of troops must nean large movements by rail or road, and it is those big movements that I think that the strategical reconnaissance would discover. I cannot altogether agree with him either as to aeroplanes being uscd as mounted infantry or as cavaliry scouts. I do not think that cavalry scouts anticipate jumping over the enemy's heads and over fences. I think a man in an aeroplane going low down across country, where he might expect to pass over extended troops at any moment, would have very little chance of fretting back with his new.s. Also, he has not got the advantage that the man on the ground has, that he can stop to locate himself. I think he moukd find it very very difficult, unless he knew the country thoroughly well, to say where he had seen anything on getting back-if he was lucky enough to do:so. I am entirely at one with the author in the conclusions that he draws, that we cannot pay too great attention to this new science or do too much to advance it and encourage it, and that we cannot make too great an effort to axaken the country to do everything in every possible way.

Captain T. G. TuLLoch, R.A. (Reserve of Officers):-The lecture to which we have had the pleasure of listening is of absorbing interest at the present time by reason of the fact that we have no aerial fleet, whilst our possible future enemies have very respectable aerial feets in being, and one of them at least has an aerial fleet which, so far as ye are concerned, may be considered overwhelming. Its superiority lies not only in its numbers, but also in its provision of hangars, or docks, and repair depots ; 
and what is of equal importance is the fact that experienced crea's are ready to man that fleet. If we purchased a ready-made flect of airshipo tomorrow we should have no place to put them in or means to inflate them, and no crews ready to man them. You can buy airships and hangars and gas plant at comparatively short notice, but there is one thing no one has ever been able to buy ready made, and that is experience. I venture to think, therefore, if the fecturer will excuse the remark, that it would have been more pertinent, under our present deplorable circumstances, had he altered the question "What use are we going to make of airships?" to "What use are other nations going to make of the airships they have already got and of those they are so rapidly building?" I make no apology for mentioning any country specifically, as I cannot see what good can come out of glossing over facts which stare us in the face, in an endeavour to disguise my meaning in dipkomatic phrascology. Besides which I honour a country whose Government looks ahcad several or many years, undeterred by the exigencies of party politics, clouded and belogged by pitiable and pitiful political opportunism. I therefore corne straight to the point and ask: "What use is Germany going to make of the fifteen airships which she already possesses and of the twenty-five or twenty: six which she will possess by the middle of next year, or of the seventy which report says she n'jll possess in about two years' time?" Not only will thase airships provided with docks and repair plant, but also with trained crens. Continuity of policy is strength, and nowhere is it better exemplified than in Germany, backed up by German thoroughness and German science. An eminent and far-seeing Frenchman said only a few days ago: "Germany, whilst preparing to become the mistress of the sea, is already mistress of the air"; to which $I$ say: " $A$ nd all honour to her for thus having been the first really to appreciate the enornous power which an overwhelming superiority in the air will confer-indeed, has already conferred upon her." Our marine flect, splendid and strong as it is in every respect, can only more in one planc; but an aerial flect can move in any plane. The strategical and tactical advantages of this are almosit incalculable, to say nothing of the moral effect. In all the considerations of live subject matter of the lecture, so ably presented to-day by Major litiden-Pouell, we must be careful to avoid criticising too closely the tcchnical, and other limitations, of the present existing types of aerial craft, and we must not base our judgment upon what they at present can not do; but rather must we look ahead and endeavour, even at the risk al being called visionaries or alarmists, to form some idea of what they nay be able to do eventually. The mord "eventually" is, however, ex. ircmely elastic-it may mean to-morrow or it may mean ten years hencebut so long as there exists the chance of its meaning ta-morrux we should eonsider the possibilitics of aerial craft accordingly. Let it be remembered That it was only on the isth of October, 1907, that Farman broke the recond by rising in an aeroplane 18 feet and travelled a distance of $3 \mathrm{Ir}$ yards; and yet only two years later he remained in the air 4 hours it minutes at Chakkons, and covered about 344 miles; whilst Paulhan, about the same time, ascended in an aeroplane to nearly 2,000 feet $!$ On the 23 rd July; 1909, Bleriot demonstrated that the United Kingdom was no longer an island, as the air knox's no shores. The curve of progress in aviation has therefore taken an extraoxdinarily rapid turn upuards during the past 1r:o years, and when one considers that for hundreds-in fact, thousandsof years previously practically no progress had been made in aviation. one is bound to ask: "What aill tomornox bring forth?" Is it unreasonable, therefore, to suggest that this country should be anakened to 
a sense of the potential danger which may come "from out the blue"; and is it not the duty of those who have studied the question to try and point out some possible-in fact, probable-forms of attack and the day to meet them? I know quite well that what I am going to say now will be botked upon by the "proh-poot" school as far-fetched, and by others as unpatriotic, as indicating to our possible opponents a certain form of attack which they otherwise might not have thought of. My reply to the former (i.c., the scoffers) is, that l have been particularly asked not to indicatc. in any way, exact tocalities, as the force of $\mathrm{my}$ arguments has cridently convinced certain well-known people of the dangers $I$ will describe, whilst as regards the question of nant of patriotism, I feel I stiould be entircly deficient in that quality if I did not endeavour to warn ny country of at any rate one particular peril 1 see ahead. Adked to this, 1 would remark that in all probability the sanje ideas which have occurred to me have also occurred to others bejond our shores. Briefly, then, I would inform you that it is possible for one airship, given reasonably fair weather, to prevent the British flet from replenishing its nagazines with cordite, and from getting practically any more manufactured for it for ncarly a year. This damage could be done by one airship in twenty-four hours; and incidentally it could as aell during that tuenty-four hours set alight the whole of the shipping. Wharics, and warehouses on the Thanies from Gravescnd upwards. This could all be done without dropping a singlc bomb or tlescending below about 3,000 feet, and without hovering over any particular spor. The statement doubtless sounds to many of you as an utter absurdity; but I can assure you that it is not considered to be other than 2 perfectly sane propasition by men in high official positions to whom I have given details, and it was those very men who agreed with me in thinking it advisable merely to hint, but not to give exact particulars of. the forn this raid attack would take. Think what it would mean if otre Navy had no reserves of cordite, and but very slou and reduced means of getting any fresh supplies manufactured. It would reduce the fleet to the position of a watch-dog, which, after a ten weeks' nar, not only couldn't bite, but which couldn't even bark! This uill give you some faint oonception of the handicap our fleet uould labour under in the event of the happening 1 have brieny described. Having indicated the disease, it is desirable to indicale the cure, or rather the prevention, which is better. In the first place, I would mention that the track of the raiding airshig, on the course 1 have in my. mind, would never once come under the fira of any guns mounted in forts, or of any mobile armament, for tho reasons: firstly, because none of the spots marked out for attack are near any forts, and even if they were, none of our forts mount any Q.F. high-angle guns; and secondly, because no $Q . F$. high-angle guns exist in this country which could be hurried up to any desired spot on diplomatic relations becoming strained. The lo-inch high-angle guns mentioned by Major Baden.Pow.ll are old muzzle-loaders, and quite useless for use against moving objects. Therefore, whilst we are building and equipping our future aerial fleet and training the crews (which may tate many months-in fact perhaps years), it is necessary, as indicated by Major Baden-Poxell, that we should, witlmut further delay, build a large number of light, high-velocity Q.F. guns on high-angle mountings, so arranged that they can be adapted to fit practically any chassis of a fairly poxerful motor car, so that in the event of a notox car breaking down badly it woukd not put a gun out of action, as in such a case the gin with its own elastic recoil mounting could be transferred to another chassis without specially fitting the sane. These guns should fire a very light shell, provided the same will give accurate 
shooting, so as to ensure very high initial velocity and easy ranging without undue stresses on the inounting, besides which a heavy shell is quite unnecessary against air craft. The shell would carry a smoke "tracer" to assist ranging and to ignite the gas in the airship. The mere knowledge that such guns existed in large numbers in this country would act as a deterrent against raid attacks, but they can never take the place of the true form of defence against an aerial fiect, the only ansuer to which is allother aerial flect. This woukd perform many functions, which have been dealt with in the lecture; but the nkre fact of the existence of an efficient and sufficiently numerous British aerial fieet would have : moral deterrent cffect which I do not think has been fully.appreciated, viz., the possibility that, with the true British love of adventure, the var misht be carried into the enemy's country, for there is no knowing what a smart young airship cornmander might not do "on his own" once he had dodgred round a cloud away from his admiral. Also, be it noted, that certain forcign nations have their eggs concentrated in fexer baskets than we have, which presumably our Intelligence Department know all about. In conclusion, I rould say that I am proposing to seisd a ketter to each candidate at the forthcoming Election, asking him to sty "Yes" or "No"-I do not want any other answer-if he is prepared, if elected, to vole for the immediate provision of an aerial fleet, suflicient, in the opinion of the naval and military advisers of the Government, for the needs of the defence of our country, and whilst that fleet is buiding. the training of an efficient corps of aeroneers and the provision of the necessary hangars, repair depots, and gas plants. There also will have to be considered the yuestion of guiding lights and charts for inland navigation and many other matters germane thereto connected with the subject of acrial defence. And now 1 must offer ny apologies for having trespassed wo kng on the good nature of this meeting. My excuse must be that I feel the danger which thrcatens our country is a very real one, and we may bitterly rue the days which we are bosing by the lukenarm and dilatory manner in which we are proceeding in the question of aerial defence. The country therefore oves a debt of gratitude to Major BadenPoxell for the great nork he has done in bringing the possibility of werial nar so forcibly to its notice, and I personally thank him for affording me an opportunity of adding my snall voice to the chorus, smath as yet, but which I hope will swell soon into an irresistible demand for deeds not suords.

Hr. J. W. Dunxe, IViltshire Regiment (Reserve of Officers):-The strategical and tactical aspects of the subject have been so thoroughly discussed this afternoon by such very capable critics that I do not think I need to speak on that subject; but as a constructor of aeroplanes, I want to draw your attention to two or three particular aspects of the case, and the nay in which they affect these military problems. I confess I am an advocate of the aeroplane and not at all of the dirigible balloon; but I xish to appear fair minded, and I aill say what I can on behalf of the dirigrible balkon. The great argument in favour of the dirigible balkon is that as you increase the size your resistance increases as the square of the linear dimensions, while your carrying capacity increases as the cube of those dimensions. If you double the over-all length dimensions of the balkon you have four times the resistance to forcing your way lisough the air, while you have eight times the carrying capacity. The aducates of this particular nay of looking at things, I think, very largely overlook the fact that the framenork of these rigid balloons is going up 
very much in the same proportion as everything else; it is going up in some cases ats more than the cube, and in very few cases as less than the cube, and long before you get to the sizes which some people advocate, you will find you are losing morc than you gain. Of course, 1 am an amateur on this matter of dirigible balkons, but my idea is that the success of the Zeppelin is not due so much to its enormous size as to the fact that the land has been distributed between two bats in tho different parts of the balkon, and therefore the strain in less on the framework. Still. ace may adnit straight off that we shall see balloons half as big again as the Zeppelin, probably carrying a considerable amount of petrol, and perhaps three motors. I do not think they will carry much in the way of inen, as men are useless up there; but they will carry a very heavy supply of bombs and combustibles. I think combustibles are of the greater importance. Whether you can drop bombs on to a mark with any accuracy or not, there is no doubt that a balloon carrying 4,000 pounds of combustibles can do a be of damage in an ordinary tou'n, dropping it haphazand anywhere. In order to make a good defence against these balkons, it is necessary to have guns in the first place, and my oun opinion is that in daylight and calm wcather, if I were asked which I woukd rather back, the balkon or the gun, I mould put ny money on the gun every time. You have only to look at the diagram the lecturer has put on the wall to see low easily the balkon can be hit under nearly all circumstances. Although we have not got the guns nox;, I think we very soon shall have them. I am perfectly certain that our ordnance people can turn out sonre sort of projectile which can explode the balkon when it hits it. l'assibly sotnething in the shape of rockets would be of advantage, and if the ordnance people cannot make them, Mr. Brock, of the Crystal Palace, I ain perfectly certain, could do so. When you come to think how extremely vulnerable these balkons are to the sort of gun that will be turned out-not the sort of gun jou have now, but a better gun altogether-you will realise that balkons will be absolutely unable to get past these guns. It follows, of course, that these airships roukd take shelter behind the clouds, and that they nould only come out on loggy days or in the night time. I don't think are shall be ever able to locate a dirigible balkon with a searchlight; the mist would reflect the rays back. As regards clouds, an airship could appear through the clouds and go back again without your seeing anything of it at all. But under those circumstances there is a far more dangerous enemy that the dirigible balloons would have to put up with, and that is the acroplane. It is on those very occasions, the cloudy and misty days and nights, that the dirigible balloons aill be liable to be attacked by the aeroplane. Generally on fine days it could see the aeroplane circling up stoply, and would have time to escape; but at night time or in cloudy weather the balkonist uould not see where the aeroplane was. Personally, I should not like to be a commander of a dirigible balkoon who had an idea that there aias a hostile acroplane up in the sky with him. The limit of speed in a balkon is very marked. Those who have gone in for naval architecture know what difliculty ae have in increasing the speed of a ship from twenty-tao to twenty-five knots, and the difficulty is exactly the same with a dirigible balkon. I do not think we shall ever be able to increase the aped of them very much over thirty-five miles an hour. The horse-power goes up as the cube of the speod, and that is a very serious matter. In the aeroplane one has more or less the same sort of thing to contend against, except that the acroplane, by reducing its area, folding its wings, oan at any time get up an enormous speed by sacrificing some of its 
bight. I do not think a couple of hundred miles an hour a.ill be anything at all exceptional. An aeroplane which is above a dirigible balkon in that way can snoop down at that sort of specd on to a balkon, trailing 2 grapnel, and rip the balloon in half and get away again. In a duel between a dirigrible balloon and an aeroplane, the balkon has no chance at all. There is, however, another aspect of this duel between the two, and that is this: the dirigible nay get away, but it has to come down somedilere sconer or later; it cannot stop in the air indefinitely, and when it is down on the ground it is perfectly helpless before aeroplane attack. An acroplane which was constructed to go past the eneny's lines to the particular swot where an anchored dirigible balkon nas noticed, would have to be one which could ny very fast and fairly far. It has got to get down pretty close to the ground to destroy the balkon, by dropping a bornb on the back of it, and it has probably to go through a rain of bullets. There may not be guns, but there will tho doubt be troops there, and the acroplane nill have to take very big risks. The aeroplanes that have been constructed by civilians are entirely useless for military purposes. They are marly all made with the lightest possible framework, generally using What is called a single intersection truss, wich means that if one bullet cuts one single wire or stick, the whole thing collapses like a pack of cards. The first essential for a militan aemoplane for going past an entmy's lines to attack dirigibles on the ground behind, is that the uing nowsk have to be so made that it can be punctured by buliets n.ithout the whole thing collapsing. which involves a sort of internal Jattice construction, and these machines uill be monoplanes, not biplanes. This lattice construction is heavier and allogether more expensive, and it rould not make for efficiency; but it seems to be the only thing for a military aero plane, and I want you to note that point. The other use to which these atroplanes would be put in nar, after the question of attacking a dirigible, is scouting, and here you want a rather different sort of nachine. In the first place, you want to go high because jou cannot sce very well if you are fying low at any great speed. You want to go some forty miles in a circle; you cho not want to keep up in the air for any length of time. because, of course, the commander wants the new's brought to him red-loot. You will not go any ahere near guns nor where you are exposed to bullets. Therefore, the particular construction for that machine is to make it very reliuble and able to fly moderately high. Probably it would carry two nxotors and a passenger, because no doubt the aemolane man xould take up a staff officer. For defence against dirigibles at night, the one essential is that the aeroplane should be able to go very high. With regard w the use of acroplanes at sea, I do not think they will be very much good. 1 do not see that an aeroplane is going to give any more information about the enemy's flcet than the fast scouts are able to do. In the first place. the speeds of the aeroplane are dependent on the speed of the nind. II an aeroplane has a speed of thirty-five miles an hour and the speed of the wind against it is the same, it simply stands still; whereas the speed of The fast scout on the surface of the water is not affected in that way. I am inclined to think you will do far better by having some sort of kite arrangement attached to the fast soouts. I do not think an acroplane will do the slightest harm to a battleship. It may have a great nooral effect at first, as the thing is neu, and it may cause a certain amount of confusion by dropping combustibles on the deck; but that will soon be stopped by the high-angle guns. There is no doubt, however, that they could destroy all sorts of small crait, such as torpedo boats and torpedo boat destroyers, and in order to destroy such craft they would fly very 
low. l'robably they would put is bomb at the end of a wire and trail it across the deck of the ship they were after. 1 believe on the shores of one of our neighbours there is a nethork of canals through which torpedo baats can pass from one part of the seabourd to another, and aeroplanes working in the way I have described might do a lot of damagre to those ships. Bejond this I do no think they will be of much use for naval nork. The point I want to impress upon you this afternoon is this : All those aeroplanes designed for those different military purposes will have to be in different classes. In the first place, you want one that will fily high; in the second place, one that will hy fast; and in the third place. one that will be bullet-proof. Even now it is quite practicable to carry an arnour plate under the man. The average acroplane of the present day has only about tho hundred pounds of spare lift that it can carry over and above the notor; therefore you cannot construct one which will possess all three of those qualitics. What the civilian constructor is foing to do with his two hundred pounds of spare lift is to put in a passenger and make him as confortable as possible, and carry a little more petrul: but he is not gaing to destroy his efticiency by buikling up his wings in the way I say, or by putting on an arnour plate, nor his chance of a sale by placing the man in a prone position, which would be absolutcly essential in a military machine. Therefore, if you aant these military aeroplanes. you will have ro design them jourselves or offer prizes for somebojdy to do it. You will not be able to pick them up on the trees or by the rosdside or buy them in any shop. They are absolutely different from those the civilian requires, as different as a torpedo bat is from a yaclit. The competition among aeroplane makers is far too keen to pernit any acroplane man to spend $\chi_{3,000}$ or $\ell_{4}, 000$ in experiments on a military aero. plane which may be refused by the Government later on. In my opinion. the kurk ought to be done by the War Office itsclf. They can sixnd money on speculative experintents which these civilian firms cannot do.

Colonel F. G. StoNe, R.A. :- I have only one criticism to offer un Major Baden-Powell's lecture, and that is that I think he is a little too canguine about the effect of musketry and revolver bullets on dirigibles. I will not quote at length the tuo passages in which he anticipates that musketri and remolver bullets nould have a more or less disastrous effect upon dirigibles, but I will qiote experiments which were made in the very thorough manner in ahich the Germans are accustoned to do everything. Last March, I think it was, two companies during their field training were given the special job of trying to destroy a dirigible-in this case a captive balloon, because for the purpose of destruction it wats not necessary it should be on the move, the destruction of the gas bag so as to bring it down by rifle fire only being aimod at. The results are probably well known to many amangst the audience here, and without entering into details I may say the results were abolutely ineffective. A good many holes were made in the gas bag, but the holes autonnatically scaled themselves up to a very great extent, and when they did not, the fits escape was so infinitesimal compared to the enormous volume of gas still remaining in the gas bag that there was not the slightest danger of the balkon being brought to earth. Perhaps Colonel Capper will correct the if I am wrong; but l take it that any dirigible may sail with perfect confidence so far as any danger from rifle bullets is concerned. There is a subject which has been touched upon once or twice at various times, but of which I think no practical solution has ever been offered, viz., how we are to protect ourselves from hostilo dirigibles at night. Coknel Capper some 
time ago, and Captain 'Tuhoch wethery rightly said that our fleet of dirigibles-which we have way the way-wouk not stand on the defensive, but would go and attack the enemy and destroy the enemy's dirigibles in theit hangars, and so on. As I say, we have not got them yet; but even supposing we do get them, and our aeronauts naturally undertake the offensive role, I do not see how that is going to prevent night attacks on certain vital areas such as Captain Tulboch alluded to somewhat obscurely but which he had previously told me about very fully. I don't see how we are going to spot these dirigibles when they come and hang -ver a vital spot, such as a condite factory or a repairing factory, or something of that sort, or how we are going to destroy them." I suggested myself electric lights, in the same way as our harbours are protected against torpedo attack, round such spots. That suggestion was naturally open to a great deal of criticism, but 1 do not remember that anybody has since made any other suggestion of a practical nature until the author this afternoon suggested aerial mine-fields. Whether that is a practical suggestion or not it is very difficult to say. In fact, I think the subject is such a difficult one that perhaps it merits rather more attention than it has hitherto received. We all talk as if hostile dirigibles nere going to be used against us during the daytime. I fancy that in Captain Tulloch's summary of the extreme danger to which we are exposed, he was thinking; from what he said to me before the lecture, more of what can be done by a dirigible in daylight than what can be done at night. I confess that a dirigible that had provided itself with maps of this country-which I have not the slightest doubt will be an accomplished fact before very long. that is to say, maps to be used by dirigibles in the air-will be able to locate such vital spots as condite factories and repairing docks with the greatest accuracy; and the experienced aeronauts whom we shall have to do with will be able to spot those points at night as well as by day. Colonel Capper has just said that he himself has been quite surprised at the facility with which our own people can locate themselves at night with comparatively small experience. What, then, may we expect from another Power with infinitely more experience and possibly more determination to use that experience to the fullest capacity? The fact still remains that, so far. as I am axare, no practical solution of this particular conundrum has been attempted to be discovered by experiment, althoug one or two solutions have been suggested. The problem is, how to protect ourselve: against attack on vital points by night?

Captain Marriort :-The ground over which I intended to go has been so completely covered by the speakers who have already spoken, especially Captain Tulbch, that $I$ have only a few rords to say to you. The jecturer spoke of the lights of towns as being one method by which airships would be able to find their way at night, but he suggests that those lights might be extinguished purposely at any time. Now, I should be very worry to be living in a town where all the lights were extinguished simply because it had been heard that we were going to be attacked immediately by an air fleet. I should hardly suppose that proper arrangements were being made for my protection under those circumstances. I cannot imagine, in fact, a town in utter darkness waiting with all its lights out for an air fleet to appear on the scene, if the town had any commonsense. We have heard a great deal about reconnaissance and other ways of finding information; but it seems to me that although that is very interesting, the vital point is, as the last speaker tells us, what are we gaing to do if we are attacked by these things? That is admitted to be 
absolutely an open question, and 1 suppose that is the rcason why we: have been all avoiding it so carcfully for so many months. I do not think I need say more than echo the sentiments of the other speakers, that there is nothing to be done but to get airships of the same sort that our possible cnemies have. With regard to the height dirigibles can reach, I understand from the lecturer that he did not apprehend they were going much higher than 5,000 fect. Balkons have actually gone up very much higher. Glaisher and Conkell are supposed to have gone up to a height of 37,000 feet; they came back alive with some difficulty. But I do not sce any reason why a dirigrible should not reach a licight of 20,000 fect. Perhaps that is because I do not understand sufficiently what there is to prevent it. I understand from the lecturer that onc-sisth of the balkoon would be taken up by an internal air balkoon; but it scenss to me that that might be improved upon, and I ste no reason why a dirigible in future should not go up to 20,000 feet, carrying oxygen for the use of those who are employed in navigating it. For that reasoul I think it is questionable whether we can depend upon our acroplanes to deal with these dirigibles in all cases, when they are so easily able rapidly to ascend to such heights. Of course, I hope that the aeroplane will be able to do such things, but it appears to me we have no immediate prospect of getting to that point.

Major B. Baden-PowrLl, in reply, said:-1 really do not think that I need detain you very long because, I am glad to say, those gentlemen who have been kind enough to criticise the lecture have rather backed up my general opinions. As regards what Colonel Capper said, I can only thank him for the valuable additions he has made to my remarks. When he criticises my observation that strategical reconnaissance woubd not be of importance at a great distance, it seems 10 me-although it is a matter of opinion-that it would be very difficult to get any real informs. tion of the movements of troops at a great distance. You may, of course, sce trains moving along from a considernble height, but it would be very difficult to say exactly what those trains contained, and where their destination might be. Then with regard to the cavalry, it seems rather to be forgotten that the cavalry, as it is, have to run great risks in reconnoitring. They go out as a rule in a given direction until they are fired on, and then they come back with the information. It might be the same u.ith the aeroplane. That pould go out a certain distance until fired upon, and then it roukd turn round and come back again, and it may come back much faster than cavalry can. Captain Tulboch said something to the cffect that I had not suggested nhat our enemies could do. Well, it is just as nell to be silent on that point. I do not want to make suggestions to them as to the reak spots we have in this oountry. Whet he made the statement that there are certain points very liable to attack, I thoroughly agree with him, because I know what he said was very trie. I feel inclined to doubt the statements he made about the Germall airships, but our information on what the different nations actually $d s$ possess or are buikding is very vague; but it is well to be prepared for the worst. I am very much in favout of what Mr. Dunne said about the designs of acroplanes for narfare. I do think that w.C ought to encourage inventors to produce a machine specially suitable for war purposes. When Cokonel Stone speaks of bullets not having any very great effect on the dirigible balkouns, I may say that I was referring to the compressed gas balkon, the non-rigid and semi-rigid. We know that the gas in those is under considerable pressure, so that a small hole in them 
will have more effect than it would on an ordinary balloon, where the gas is not under pressure. Although I do not say that you could bring a balkon down at once by putting a few bultets through it, it is to be remembered that that balloon, directly it gets a little bit flabby and loose, loses its manceuvring power, and is unable to kecp up its speed; therefore, as 1 said in the paper, it is unlikely to be able to get back to its own lines. Captain Marriott spoke about the difficulties of extinguishing the lights of a town; but I do not know that there is any very great difficulty in that. We know how in the war in South Africa, for instance, it pus sometimes ruled that all lights were to be put out at a certain time and the towns, were in absolute darkness. As for the reason why a dirigible slould not go high, that is, as every balloonist knows, a matter of size. If you require a balloon to go up to a height of 20,000 feet, you would have to infate it only about one-third full-that is to say, it would be only able to lift onc-third the reight off the ground that it coukd lift if it were completely filled, and that of course is a considerable objection. You would have to make the machine so very much larger than is necessary if you are not going to that great height. I think those are sufficient answers to the questions, and I can only thank you very much for the kind way in which you have listened to the remarks, and thank the speakers for the addition they have made to the paper.

The Chairsar (Admiral of the Fleet Sir G. H. U. Noel):-Before asking you to accord a vote of thanks to the author, I should just like to make a few remarks. I think in this question we may say that we are all "in the air." It is something to be on the sea instead of on the land, but when you get into the air, I think we are perhaps a little less certain of where we are. Dirigibles are no doubt the great offensive air machines: they can carr material that will do harm; but 1. think there is very little doubt that they will have to act at night if they want to do real damage. They can then perhaps approach unseen and hover over the position and do a great deal of damage. It seems to me that navigating in the air must be a very considerable difficulty. If you are up in the air in the dark, how can you tell one town from the other? How can you tell one position from another? It must be a matter of years of experierice for an aeronaut to be thoroughly an fait at navigating, and 1 think it will be years yet before aerial navigation will be thoroughly understood and a-real danger. Now as regards the aeroplane. We in England in all these, matters are generally very much behind, but $I$ always consider that the English in the end come out on top. We can all remember when motors first came across the Channel; practically every motor you saw had a foreigner for a chauffeur; but what is the case now? We have thousands and thousands of chauffeurs, all English. Aeroplanes are now beginning to take hold; and there are mundreds of young fellows only too anxious to get up into the air, and 1 believe that our real defence will consist in being able to put a large number of people into the ait on aeroplanes. The enemy will then have to think twice before he comes across the Channel. It is the aeroplane that is the sporting thing and appeals to the Britisher, and it is the aeroplane, I believe, that will be our true defence. We have heard a very interesting discussion, especially from Captain Tulloch, Colonel Capper, and Mr. Dunne, the latter interesting us as an experienced constructor of aeroplanes. I think from the paper, combined with the discussion, we have learned a very great deal to-day. 1 therefore conceive it my duty to express on your behalf our grateful thanks to the lecturer for his lecture. 